\title{
PENGARUH PENGGUNAAN SEKAM PADI DALAM RANSUM BERBASIS LIMBAH PANGAN HOTEL KERING TERHADAP PERTUMBUHAN DAN KARKAS BABI
}

\section{THE EFFECT OF RICE HULL IN THE DRIED HOTEL FOOD WASTE BASED-DIET ON THE GROWTH AND CARCASS OF PIGS}

\author{
I Made Purnamartha, Setiyono, dan Panjono* \\ Fakultas Peternakan, Universitas Gadjah Mada, Jl. Fauna No. 3, Bulaksumur, Yogyakarta, 55281
}

\section{INTISARI}

Penelitian bertujuan untuk mengetahui pengaruh penggunaan sekam padi sebagai sumber serat dalam ransum berbasis limbah pangan hotel kering terhadap pertumbuhan dan karakteristik karkas ternak babi. Dua puluh empat ekor babi persilangan Landrace x Yorkshire jantan kastrasi, dengan umur 2 bulan dan berat badan 26,15 $\pm 0,73 \mathrm{~kg}$ dibagi dalam empat kelompok perlakuan ransum, yaitu tanpa sekam padi (R0), 10\% sekam padi (R1), 20\% sekam padi (R2), dan 30\% sekam padi (R3). Penelitian menggunakan kandang individu dengan lantai beton, berukuran panjang 1,9 $\mathrm{m}$ dan lebar 0,5 m. Pakan diberikan secara ad libitum. Pengamatan dilaksanakan selama 10 minggu. Data yang diperoleh dianalisis dengan Rancangan Acak Lengkap pola searah. Apabila terdapat perbedaan, analisis dilanjutkan dengan menggunakan Duncan's new Multiple Range Test. Hasil penelitian menunjukkan bahwa konsumsi pakan kelompok R1

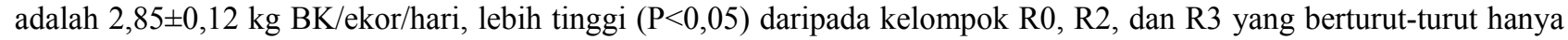
$2,66 \pm 0,86 ; 2,64 \pm 0,04$ dan 2,63 $\pm 0,03 \mathrm{~kg}$ BK/ekor/hari. Konsumsi pakan berdasarkan berat badan metabolis kelompok $\mathrm{R} 0$ adalah $126,11 \pm 2,97 \mathrm{~g} \mathrm{BK} / \mathrm{kg} \mathrm{BB}^{0,75} /$ hari, lebih rendah $(\mathrm{P}<0,05)$ daripada $\mathrm{R} 1$ yaitu $131,32 \pm 2,07 \mathrm{~g} \mathrm{BK} / \mathrm{kg} \mathrm{BB}^{0,75} / \mathrm{hari}$. Berat badan akhir, pertambahan berat badan harian, berat potong, berat karkas, dan loin eye area kelompok R3 berturutturut adalah $84,33 \pm 4,67 \mathrm{~kg} ; 0,83 \pm 0,06 \mathrm{~kg} / \mathrm{ekor} / \mathrm{hari} ; 83,83 \pm 3,40 \mathrm{~kg} ; 53,50 \pm 1,80 \mathrm{~kg}$ dan $29,00 \pm 2,65 \mathrm{~cm}^{2}$, lebih rendah $(\mathrm{P}<0,05)$ daripada R1 yang berturut-turut $95,00 \pm 4,37 \mathrm{~kg} ; 0,98 \pm 0,06 \mathrm{~kg} / \mathrm{ekor} / \mathrm{hari} ; 92,33 \pm 2,89 \mathrm{~kg} ; 67,83 \pm 0,58 \mathrm{~kg}$ dan $35,67 \pm 2,52 \mathrm{~cm}^{2}$. Konversi pakan kelompok R3 adalah 3,18 $\pm 0,20$, lebih tinggi $(\mathrm{P}<0,05)$ daripada R0 dan R1 yang

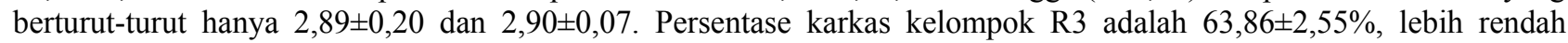
$(P<0,05)$ daripada ketiga kelompok lainnya yang berturut-turut $72,88 \pm 0,96 ; 73,51 \pm 2,09$ dan $70,71 \pm 0,33 \%$. Lemak punggung kelompok $\mathrm{R} 0$ adalah $3,55 \pm 0,16 \mathrm{~cm}$, lebih tebal $(\mathrm{P}<0,05)$ daripada $\mathrm{R} 2$ dan $\mathrm{R} 3$ yang berturut-turut hanya $2,97 \pm 0,35$ dan 2,48 $\pm 0,19 \mathrm{~cm}$. Disimpulkan bahwa penggunaan sekam padi pada konsentrasi $10 \%$ dalam ransum berbasis limbah pangan hotel kering mampu meningkatkan pertumbuhan dan karkas ternak babi.

(Kata kunci: Sekam padi, Limbah pangan hotel, Pertumbuhan, Karkas, Babi)

\section{ABSTRACT}

The study was conducted to observe the effect of rice hull as a fiber source in the dried hotel food waste baseddiet on the growth and carcass characteristics of pigs. Twenty four of 2 month old and $26.15 \pm 0.73 \mathrm{~kg}$ initial body weight Landrace $x$ Yorkshire cross barrow were randomly divided into four treatment groups, i.e. without rice hull (R0), 10\% rice hull (R1), 20\% rice hull (R2), and 30\% rice hull (R3), each group consisted of six individual pigs. The study used individual concrete pen with $1.9 \mathrm{~m}$ in length and $0.5 \mathrm{~m}$ in width. Feed was given as ad libitum. Observation carried out for 10 weeks. The obtained data were analyzed using one-way ANOVA based on Completely Randomized Design and if there were significant differences, continued mean analyses with Duncan's new Multiple Range Test for significant differences. The results showed that the feed intake was higher $(P<0.05)$ in R1, which was $2.85 \pm 0.12 \mathrm{~kg}$ DM.head $d^{-1}$.day ${ }^{-1}$, than in the other of three groups, which were 2.66 $\pm 0.86 ; 2.64 \pm 0.04$ and $2.63 \pm 0.03 \mathrm{~kg} \mathrm{DM.head^{-1 } \text { . day }}$ ${ }^{1}$, respectively. Feed intake based on metabolic body weight was lower $(P<0.05)$ in R0, which was $126.11 \pm 2.97 \mathrm{~g}$

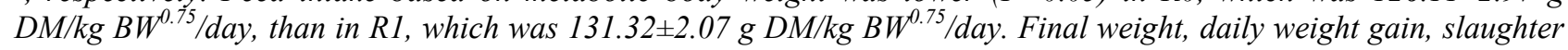
weight, carcass weight and loin eye area in $R 3$ were lower $(P<0.05)$ than in R1. Feed conversion was higher $(P<0.05)$ in R3, which was $3.18 \pm 0.20$, than in $R 0$ and $R 1$, which were $2.89 \pm 0.20$ and $2.90 \pm 0.07$, respectively. Carcass percentage was lower $(P<0.05)$ in $R 3$, which was $63.86 \pm 2.55 \%$, than in the other of three groups, which were $72.88 \pm 0.96$; $73.51 \pm 2.09$ and $70.71 \pm 0.33 \%$, respectively. Backfat thickness was higher $(P<0.05)$ in R0, which was $3.55 \pm 0.16 \mathrm{~cm}$, than in $R 2$ and $R 3$, which were $2.97 \pm 0.35$ and $2.48 \pm 0.19 \mathrm{~cm}$, respectively. It is concluded that the use of $10 \%$ rice hull in the dried hotel food waste based-diet can increase growth and carcass of the pigs.

(Key words: Rice hull, Hotel food waste, Growth, Carcass, Pigs)

\footnotetext{
* Korespondensi (corresponding author):

Telp. +62 274 513363, Faks. +62 274521578

E-mail: panjono@mail.ugm.ac.id
} 


\section{Pendahuluan}

Perbaikan ekonomi dan pariwisata serta peningkatan jumlah penduduk menyebabkan peningkatan permintaan terhadap daging babi. Hal ini terlihat dari jumlah pemotongan ternak babi di Indonesia yang meningkat dari tahun 2008 sampai 2011 yaitu secara berturut-turut $691.837 ; 783.156$; 816.416 dan 859.546 ekor/tahun (Badan Pusat Statistik, 2012). Jumlah pemotongan ternak babi pada tahun tersebut menempati urutan kedua teratas setelah sapi potong.

Sejak adanya insiden beberapa penyakit seperti atherosclerosis, tekanan darah tinggi, dan jantung koroner yang diduga berkaitan dengan tingginya kandungan lemak dan kolesterol pangan, maka konsumen berusaha menghindari makanan berupa produk hewani dengan kandungan lemak dan kolesterol yang tinggi. Contoh produk hewani dengan kandungan lemak tinggi yaitu pada babi yang diberi ransum mengandung 40\% limbah pangan hotel kering menghasilkan lemak punggung $19,77 \%$ lebih tebal daripada ternak babi yang diberi ransum tanpa limbah pangan hotel kering (Chae et al., 2000).

Produksi ternak babi selain diarahkan untuk menghasilkan daging dengan kualitas yang baik, juga diupayakan untuk menekan biaya produksi yang tinggi. Pakan merupakan faktor biaya produksi tertinggi yaitu sekitar $55-85 \%$ dari total biaya produksi. Limbah pangan hotel merupakan salah satu bahan pakan hasil sisa industri dengan harga murah, tetapi memiliki nilai gizi yang cukup tinggi.

Limbah pangan hotel memiliki kelemahan seperti lemak kasar dan kadar air yang tinggi, serta serat kasar yang rendah. Bidura et al. (2008) menyatakan bahwa kandungan lemak kasar dalam limbah pangan hotel yaitu 18,41-23,92\%, sedangkan dengan analisis bahan pakan secara proksimat pada penelitian ini diperoleh kandungan lemak kasar limbah pangan hotel sebesar 14,31\%. Pemberian ransum yang mengandung limbah pangan hotel menyebabkan peningkatan persentase lemak karkas dan menurunkan persentase daging babi (Westendorf, 2000). Harris (2002) menyatakan bahwa standar lemak karkas babi yang direkomendasikan United States Department of Agriculture adalah 19-20\%.

Mengantisipasi permasalahan di atas, maka pemberian limbah pangan hotel perlu diimbangi dengan penambahan serat berupa sekam padi untuk mengurangi pengaruh lemak dalam limbah pangan hotel. Budaarsa (1997) melaporkan bahwa penggunaan sekam padi hingga konsentrasi $10 \%$ dalam ransum babi yang mengandung 10\% lemak tallow dapat menurunkan 14,71\% lemak karkas babi. Penelitian penggunaan sekam padi dalam ransum itik dilaporkan oleh Yadnya dan Sukmawati (2006), yang mendapatkan bahwa penggantian $50 \%$ dedak dengan sekam padi yang disuplementasi $0,2 \%$ starbio menurunkan pertambahan berat badan dan efisiensi penggunaan ransum itik. Hasil penelitian Fraga et al. (1991) mendapatkan bahwa penggunaan $11 \%$ sekam padi dalam ransum kelinci menghasilkan konsumsi bahan kering yang lebih rendah daripada penggunaan $27 \%$ rumput alfalfa dan $25 \%$ ampas anggur. Penelitian bertujuan untuk mengetahui pengaruh penggunaan sekam padi sebagai sumber serat dalam ransum berbasis limbah pangan hotel kering terhadap pertumbuhan dan karakteristik karkas ternak babi.

\section{Materi dan Metode}

Penelitian ini menggunakan 24 ekor babi persilangan Landrace x Yorkshire jantan kastrasi, dengan umur 2 bulan dan berat badan rata-rata $26,15 \pm 0,73 \mathrm{~kg}$. Bahan pakan yang digunakan terdiri dari tepung jagung, tepung ikan, wheat pollard, bungkil kelapa dan limbah hotel sebagai bahan pakan utama, serta sekam padi sebagai bahan pakan perlakuan. Penelitian menggunakan empat kelompok perlakuan level sekam padi dalam ransum yaitu ransum tanpa sekam padi (R0), ransum mengandung $10 \%$ sekam padi (R1), ransum mengandung $20 \%$ sekam padi (R2) dan ransum mengandung $30 \%$ sekam padi (R3), masing-masing kelompok terdiri atas enam ekor ternak. Kandang yang digunakan adalah kandang individu dengan lantai beton berukuran panjang 1,9 $\mathrm{m}$, dan lebar 0,5 $\mathrm{m}$. Kandang dilengkapi dengan tempat makan dan minum, thermometer serta higrometer.

Pengolahan limbah pangan hotel dilakukan menurut metode Westendorf et al. (1998) yang meliputi tahapan penyortiran dan perebusan, sedangkan tahapan pengeringan, penggilingan dan penyimpanan dilakukan menurut metode Yanis et al. (2000). Sekam padi yang digunakan berasal dari padi jenis Serang yang digiling menggunakan mesin merk Honda GX 160 dilengkapi saringan berdiameter lubang $1 \mathrm{~mm}$. Seluruh bahan pakan yang digunakan dalam penelitian dianalisis kandungan nutriennya. Kandungan nutrien ransum disusun berdasarkan rekomendasi National Research Council (1998) serta Kyriazakis dan Whittemore (2006). Komposisi dan kandungan nutrien ransum tersaji pada Tabel 1.

Babi sebanyak 24 ekor sebelumnya telah diidentifikasi dengan pemberian nomor, digunakan dalam penelitian ini, selanjutnya dilakukan pengacakan tempat dan perlakuan. Ternak babi kemudian diadaptasikan dengan kandang dan pakan selama satu minggu. Pengamatan dilaksanakan selama 10 minggu. Berat badan awal diperoleh 
Tabel 1. Komposisi dan kandungan nutrien ransum penelitian (composition and nutrient content of feed experiment)

\begin{tabular}{|c|c|c|c|c|c|c|}
\hline $\begin{array}{c}\text { Berat }(\mathrm{kg}) \\
(\text { weight } \\
(\mathrm{kg}))\end{array}$ & Variabel (variable) & R0 & R1 & R2 & R3 & $\begin{array}{l}\text { Standar } \\
\text { (standard) }\end{array}$ \\
\hline \multirow[t]{16}{*}{$20-50$} & Bahan pakan (\%) (feedstuffs (\%)) & & & & & \\
\hline & Limbah pangan hotel (hotel food waste) & 50,0 & 50,0 & 50,0 & 50,0 & \\
\hline & Sekam padi (rice hull) & - & 10,0 & 20,0 & 30,0 & \\
\hline & Pollard (pollard) & 7,0 & 7,0 & 3,0 & 1,0 & \\
\hline & Tepung jagung (corn meal) & 28,0 & 20,0 & 5,0 & 1,0 & \\
\hline & Tepung ikan (fish meal) & 8,0 & 10,0 & 10,0 & 12,0 & \\
\hline & Bungkil kelapa (coconut meal) & 7,0 & 3,0 & 12,0 & 6,0 & \\
\hline & Jumlah $($ total $)$ & 100,0 & 100,0 & 100,0 & 100,0 & \\
\hline & Kandungan nutrien (nutrient content) & & & & & \\
\hline & Bahan kering (\%) (dry matter (\%)) & 90,8 & 91,1 & 91,9 & 92,1 & $90^{\mathrm{a}}$ \\
\hline & $\begin{array}{l}\text { Energi metabolis }(\mathrm{kcal} / \mathrm{kg}) \\
(\text { metabolizable energy }(\mathrm{kcal} / \mathrm{kg}) \text { ) }\end{array}$ & 3274,8 & 3280,5 & 3263,2 & 3246,0 & $3265,0^{\mathrm{a}}$ \\
\hline & Protein kasar $(\%)$ (crude protein $(\%))$ & 18,0 & 18,1 & 18,0 & 17,9 & $18,0^{\mathrm{a}}$ \\
\hline & Lemak kasar (\%) (crude fat (\%)) & 10,4 & 9,6 & 10,4 & 9,2 & $7,0^{\mathrm{b}}$ \\
\hline & Serat kasar (\%) (crude fiber (\%)) & 1,7 & 4,1 & 6,8 & 9,0 & $4,0^{\mathrm{b}}$ \\
\hline & Kalsium (\%) (calcium (\%)) & 1,4 & 1,4 & 1,6 & 1,6 & $0,6^{\mathrm{a}}$ \\
\hline & Fosfor (\%) (phosphorus (\%)) & 0,8 & 0,8 & 0,9 & 0,8 & $0,5^{\mathrm{a}}$ \\
\hline \multirow[t]{16}{*}{$50-80$} & Bahan pakan (\%) (feedstuffs (\%)) & & & & & \\
\hline & Limbah pangan hotel (hotel food waste) & 50,0 & 50,0 & 50,0 & 50,0 & \\
\hline & Sekam padi (rice hull) & & 10,0 & 20,0 & 30,0 & \\
\hline & Pollard (pollard) & 12,0 & 2,0 & 9,0 & 1,0 & \\
\hline & Tepung jagung (corn meal) & 30,0 & 30,0 & 3,0 & 1,0 & \\
\hline & Tepung ikan (fish meal) & 3,0 & 6,0 & 4,0 & 7,0 & \\
\hline & Bungkil kelapa (coconut meal) & 5,0 & 2,0 & 14,0 & 11,0 & \\
\hline & Jumlah (total) & 100,0 & 100,0 & 100,0 & 100,0 & \\
\hline & Kandungan nutrien (nutrient content) & & & & & \\
\hline & Bahan kering (\%) (dry matter (\%)) & 90,5 & 90,8 & 91,8 & 92,1 & $90^{\mathrm{a}}$ \\
\hline & $\begin{array}{l}\text { Energi metabolis }(\mathrm{kcal} / \mathrm{kg}) \\
(\text { metabolizable energy }(\mathrm{kcal} / \mathrm{kg}))\end{array}$ & 3278,2 & 3270,4 & 3265,3 & 3249,6 & $3265,0^{\mathrm{a}}$ \\
\hline & Protein kasar $(\%)$ (crude protein (\%)) & 15,5 & 15,5 & 15,4 & 15,6 & $15,5^{\mathrm{a}}$ \\
\hline & Lemak kasar (\%) (crude fat (\%)) & 9,8 & 9,2 & 10,3 & 9,6 & $5,5^{\mathrm{b}}$ \\
\hline & Serat kasar (\%) (crude fiber (\%)) & 1,9 & 4,0 & 7,1 & 9,3 & $5,0^{\mathrm{b}}$ \\
\hline & Kalsium (\%) (calcium (\%)) & 1,1 & 1,2 & 1,4 & 1,4 & $0,5^{\mathrm{a}}$ \\
\hline & Fosfor (\%) (phosphorus (\%)) & 0,6 & 0,7 & 0,8 & 0,8 & $0,4^{\mathrm{a}}$ \\
\hline
\end{tabular}

R0: sekam padi $0 \%$, R1: sekam padi $10 \%$, R2: sekam padi $20 \%$, R3: sekam padi $30 \%$ (R0: $0 \%$ rice hull, R1: $10 \%$ rice hull, $R 2: 20 \%$ rice hull, $R 3: 30 \%$ rice hull).

${ }^{a}$ Standar National Research Council, 1998 (standard of National Research Council, 1998).

b Standar Kyriazakis dan Whittemore, 2006 (standard of Kyriazakis and Whittemore, 2006).

dengan menimbang berat badan masing-masing ternak pada awal periode pemeliharaan. Suhu dan kelembaban kandang selama penelitian berturutturut adalah $29,03 \pm 1,01^{\circ} \mathrm{C}$ dan $61,76 \pm 2,80 \%$.

Pencampuran ransum dilakukan setiap satu minggu sekali. Ransum dan air minum diberikan secara ad libitum. Penimbangan sisa ransum dilakukan pada pagi hari menggunakan timbangan duduk kapasitas $10 \mathrm{~kg}$ (ketelitian $50 \mathrm{~g}$ ). Koleksi sampel sisa ransum dilakukan selama satu minggu setiap akhir periode penggemukan. Penimbangan ternak dilakukan setiap dua minggu sekali menggunakan timbangan gantung kapasitas $100 \mathrm{~kg}$ (ketelitian $500 \mathrm{~g}$ ).

Ternak babi dipotong pada akhir periode pengamatan dengan sebelumnya dipuasakan selama 12 jam. Tahapan pemotongan mengikuti prosedur Boggs et al. (2006) yang meliputi pemingsanan dengan metode elektrik, pengeluaran darah, pelepasan bulu, pengeluaran organ dalam dan pengerjaan karkas. Berat potong diketahui dengan menimbang ternak babi sesaat sebelum pemotongan. Berat karkas diperoleh dengan menimbang karkas segera setelah selesai proses 
pengerjaan karkas. Tebal lemak punggung diukur pada tiga lokasi pengukuran, yaitu di atas tulang rusuk pertama, tulang rusuk terakhir dan persendian paha menggunakan jangka sorong. Pengukuran loin eye area dilakukan dengan melukis penampang otot Longissimus dorsi di antara tulang rusuk ke-10 dan ke-11, kemudian dihitung dengan milimeter blok.

Data yang diperoleh dianalisis dengan Rancangan Acak Lengkap pola searah. Apabila terdapat perbedaan, analisis dilanjutkan dengan menggunakan Duncan's new Multiple Range Test (Steel dan Torrie, 1993). Pengolahan data dilakukan dengan menggunakan bantuan program SPSS versi 16.0 for windows (Statistical Product and Service Solutions Inc, 2007).

\section{Hasil dan Pembahasan}

\section{Pertumbuhan ternak babi}

Konsumsi pakan kelompok R1 lebih tinggi $(\mathrm{P}<0,05)$ daripada R0 (Tabel 2). Hasil ini menunjukkan bahwa pemberian $10 \%$ sekam padi menyebabkan penurunan tingkat kecernaan energi ransum, sehingga babi pada kelompok R1 berusaha memenuhi kebutuhan energinya dengan mengonsumsi ransum yang lebih banyak daripada kelompok R0. Hasil ini sesuai dengan pendapat Noblet dan Le Goff (2001) yang menyatakan bahwa energi dari serat kasar yang dapat dicerna dari keseluruhan energi ransum sangat rendah.

Konsumsi pakan kelompok R2 dan R3 lebih rendah $(\mathrm{P}<0,05)$ daripada $\mathrm{R} 1$ (Tabel 2). Penurunan konsumsi ini terjadi karena sifat bulky yang dimiliki oleh sekam padi, sehingga ternak menjadi lebih cepat kenyang walaupun kebutuhan nutriennya belum terpenuhi. Hasil ini sesuai dengan pendapat BoGohl (1975) cit. Mastika (2009) yang menyatakan bahwa sekam padi memiliki angka densitas $0,25 \mathrm{~g} / \mathrm{cm}^{3}$ yang berarti setiap volume $1 \mathrm{~cm}^{3}$ hanya dapat diisi oleh $0,25 \mathrm{~g}$ sekam padi.

Konsumsi bahan kering pakan berdasarkan berat badan metabolis pada kelompok R1 lebih tinggi $(\mathrm{P}<0,05)$ daripada $\mathrm{R} 0$ (Tabel 2). Tingginya kandungan lemak ransum $\mathrm{R} 0$ akibat penggunaan limbah pangan hotel yang tidak diimbangi dengan penambahan sekam padi mengakibatkan kebutuhan energi lebih cepat terpenuhi, sehingga ternak babi mengkonsumsi pakan yang lebih sedikit. Konsumsi ini lebih tinggi daripada estimasi konsumsi pakan ternak babi pada berat $20-80 \mathrm{~kg}$ yang direkomendasikan oleh National Research Council (1998) yaitu $120 \mathrm{~g} / \mathrm{kg} \mathrm{BB}{ }^{0,75} /$ hari yang menandakan ternak babi dalam keadaan sehat serta kemungkinan ransum yang digunakan pada penelitian ini lebih disukai oleh ternak.

Berat badan awal di antara keempat kelompok berbeda tidak nyata (Tabel 2). Berat badan akhir kelompok R1 lebih tinggi $(\mathrm{P}<0,05)$ daripada R2 dan R3 (Tabel 2). Hasil ini disebabkan karena konsumsi pakan ternak babi kelompok R1 merupakan yang paling tinggi. Hasil ini sama dengan yang dilaporkan oleh Jin et al. (1994), dan Len et al. (2008), yaitu pemberian serat pada konsentrasi yang paling tinggi akan menurunkan berat akhir ternak babi.

Pertambahan berat badan harian kelompok R1 lebih tinggi $(\mathrm{P}<0,05)$ daripada $\mathrm{R} 2$ dan $\mathrm{R}$, demikian juga pertambahan berat badan harian kelompok R0 lebih tinggi $(\mathrm{P}<0,05)$ daripada $\mathrm{R} 3$ (Tabel 2). Hasil ini disebabkan karena ternak babi kelompok R1 mampu menghasilkan berat badan akhir yang lebih tinggi daripada R2 dan R3. Konsumsi pakan pada kelompok R1 yang lebih tinggi juga menyebabkan pertambahan berat badan harian ternak menjadi lebih baik. Hal ini sesuai dengan pendapat Whittemore dan Kyriazakis (2006), yaitu jumlah konsumsi pakan dapat menentukan kecukupan nutrien yang dibutuhkan ternak babi.

Berdasarkan grafik laju pertumbuhan ternak babi (Gambar 1) terlihat bahwa ternak babi kelompok R1 memiliki kenaikan berat badan yang paling konsisten, sedangkan kelompok R3 menghasilkan pola pertumbuhan awal yang rendah. Hal ini disebabkan karena pemberian sekam padi pada konsentrasi $10 \%$ mampu meningkatkan asupan nutrien untuk pertumbuhan yang terlihat dari peningkatan konsumsi, tanpa berdampak negatif terhadap nafsu makan ternak karena belum mengganggu kapasitas tampung lambung. Hasil ini sesuai dengan pendapat Wenk (2001) yang menyatakan bahwa komposisi dan jumlah sumber serat yang diberikan selain akan mempengaruhi waktu transit makanan juga berpengaruh pada proses pencernaan di lambung.

Konversi pakan kelompok R0 dan R1 lebih rendah $(\mathrm{P}<0,05)$ daripada $\mathrm{R} 3$ (Tabel 2). Nilai ini menunjukkan bahwa ternak babi pada perlakuan R0 dan R1 lebih efisien dalam mengkonversi ransum yang diberikan menjadi satuan berat badan. Tingginya konversi pakan kelompok R3 disebabkan karena kandungan sekam padi yang tinggi dalam ransum, sehingga berakibat pada rendahnya tingkat pertumbuhan ternak babi. Hasil penelitian ini sama dengan yang pernah dilaporkan oleh Shriver et al. (2003) dan Len et al. (2008) yaitu penggunaan serat tinggi dalam ransum babi akan meningkatkan nilai konversi pakan yang diperoleh.

\section{Karkas ternak babi}

Berat potong kelompok R1 lebih tinggi $(\mathrm{P}<0,05)$ daripada $\mathrm{R} 2$ dan R3 (Tabel 3). Hasil ini sejalan dengan data berat badan akhir dari setiap kelompok pada penelitian ini, karena berat potong 
Tabel 2. Pengaruh penggunaan sekam padi dalam ransum berbasis limbah pangan hotel kering terhadap pertumbuhan ternak babi (effect of the use rice hull in the dried hotel food waste based-diet on the growth of pigs)

\begin{tabular}{|c|c|c|c|c|}
\hline Variabel (variable) & R0 & R1 & $\mathrm{R} 2$ & R3 \\
\hline $\begin{array}{l}\text { Konsumsi pakan (kg BK/ekor/hari) } \\
\text { (daily feed intake (kg } \\
\text { DM/head/day)) }\end{array}$ & $2,66 \pm 0,86^{\mathrm{b}}$ & $2,85 \pm 0,12^{\mathrm{a}}$ & $2,64 \pm 0,04^{\mathrm{b}}$ & $2,63 \pm 0,03^{b}$ \\
\hline $\begin{array}{l}\text { Konsumsi pakan (g BK/kg } \\
\mathrm{BB}^{0,75} / \text { hari) (daily feed intake ( } g \\
\left.D M / \mathrm{kg} \mathrm{BW}^{0,75} / \text { day }\right) \text { ) }\end{array}$ & $126,11 \pm 2,97^{\mathrm{b}}$ & $131,32 \pm 2,07^{\mathrm{a}}$ & $128,78 \pm 3,46^{\mathrm{ab}}$ & $129,76 \pm 3,37^{\mathrm{ab}}$ \\
\hline $\begin{array}{l}\text { Berat badan awal (kg) (initial body } \\
\text { weight }(\mathrm{kg}) \text { ) }\end{array}$ & $26,00 \pm 0,95$ & $26,17 \pm 0,68$ & $26,17 \pm 0,82$ & $26,25 \pm 0,61$ \\
\hline $\begin{array}{l}\text { Berat badan akhir (kg) (final body } \\
\text { weight }(\mathrm{kg}) \text { ) }\end{array}$ & $90,75 \pm 6,28^{\mathrm{ab}}$ & $95,00 \pm 4,37^{\mathrm{a}}$ & $86,00 \pm 5,68^{\mathrm{b}}$ & $84,33 \pm 4,67^{\mathrm{b}}$ \\
\hline $\begin{array}{l}\text { PBBH (kg/ekor/hari) (daily weight } \\
\text { gain (kg/head/day)) }\end{array}$ & $0,93 \pm 0,08^{a b}$ & $0,98 \pm 0,06^{\mathrm{a}}$ & $0,86 \pm 0,08^{\mathrm{bc}}$ & $0,83 \pm 0,06^{\mathrm{c}}$ \\
\hline $\begin{array}{l}\text { PBBH (\% berat awal) (daily weight } \\
\text { gain }(\% \text { initial weight }))\end{array}$ & $3,56 \pm 0,26^{\mathrm{ab}}$ & $3,76 \pm 0,17^{\mathrm{a}}$ & $3,27 \pm 0,35^{\text {bc }}$ & $3,16 \pm 0,19^{\mathrm{c}}$ \\
\hline Konversi pakan (feed conversion) & $2,89 \pm 0,20^{\mathrm{b}}$ & $2,90 \pm 0,07^{\mathrm{b}}$ & $3,10 \pm 0,25^{\mathrm{ab}}$ & $3,18 \pm 0,20^{\mathrm{a}}$ \\
\hline
\end{tabular}

R0: sekam padi $0 \%$, R1: sekam padi $10 \%$, R2: sekam padi $20 \%$, R3: sekam padi $30 \%$ (R0: $0 \%$ rice hull, $R 1$ : 10\% rice hull, $R 2: 20 \%$ rice hull, $R 3: 30 \%$ rice hull).

PBBH: pertambahan berat badan harian (daily weight gain).

a,b,c Superskrip yang berbeda pada baris yang sama menunjukkan perbedaan yang nyata $(\mathrm{P}<0,05)($ different superscripts at the same row indicate significant differences $(P<0.05))$.

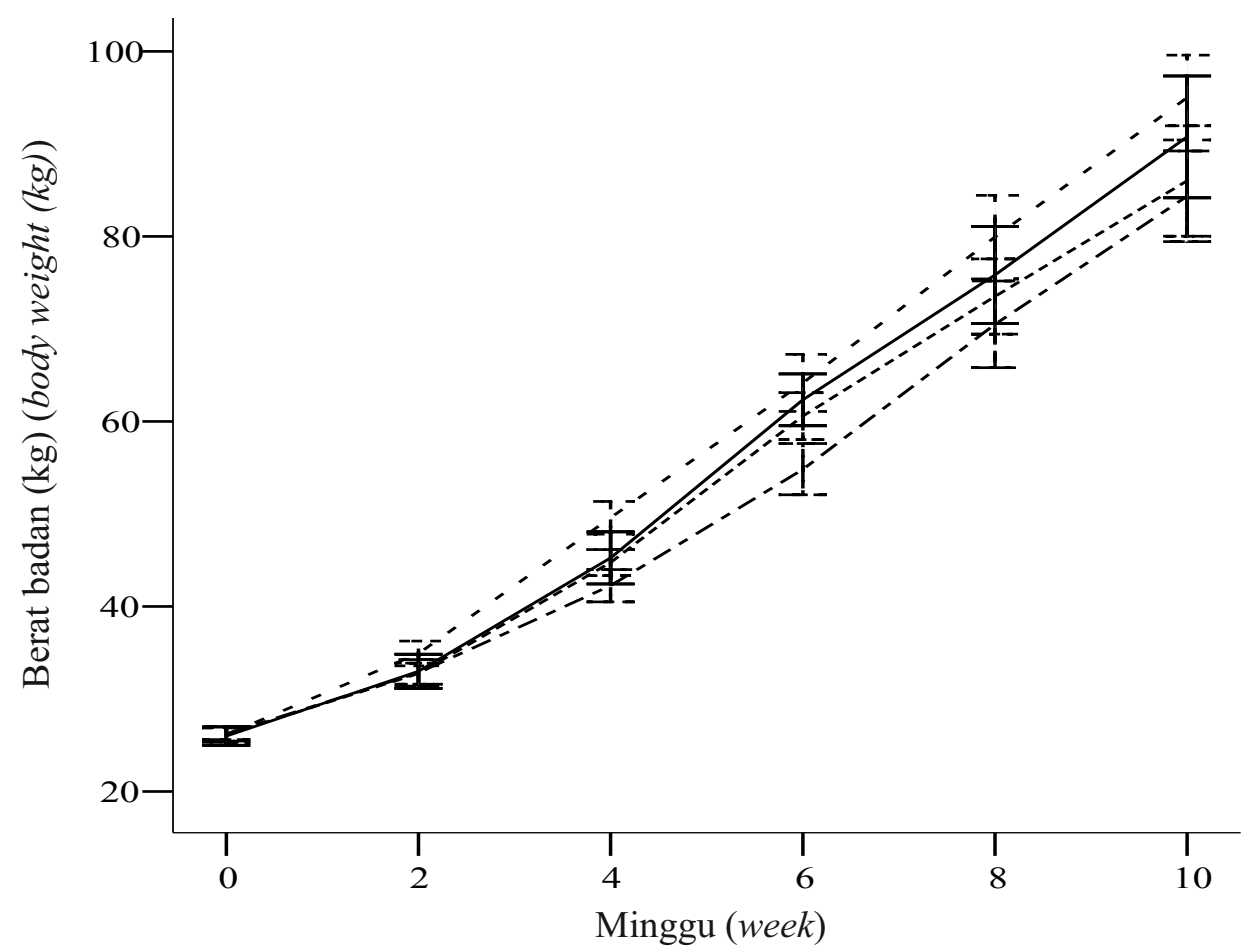

Gambar 1. Grafik pertambahan berat badan ternak babi (the graph of pig's body weight gain) (R0:-

$$
\text { R1:- - -, R2:----., R3:---). }
$$

babi sangat dipengaruhi oleh pertumbuhan babi selama pemeliharaan. Hasil ini sesuai dengan yang dilaporkan Knowles et al. (1998) dan Len et al. (2008) yang mendapatkan bahwa pemberian serat pada konsentrasi yang tinggi akan menurunkan berat potong.

Berat karkas kelompok R0 dan R1 lebih tinggi $(\mathrm{P}<0,05)$ daripada $\mathrm{R} 2$ dan $\mathrm{R} 3$, demikian pula berat karkas kelompok R2 lebih tinggi $(\mathrm{P}<0,05)$ 
Tabel 3. Pengaruh penggunaan sekam padi dalam ransum berbasis limbah pangan hotel kering terhadap karkas ternak babi (effect of the use rice hull in the dried hotel food waste based-diet on the carcass of pigs)

\begin{tabular}{lcccc}
\hline \hline \multicolumn{1}{c}{ Variabel (variable) } & $\mathrm{R} 0$ & $\mathrm{R} 1$ & $\mathrm{R} 2$ & $\mathrm{R} 3$ \\
\hline $\begin{array}{l}\text { Berat potong (kg) (slaughter weight } \\
(\mathrm{kg}))\end{array}$ & $89,17 \pm 2,47^{\mathrm{ab}}$ & $92,33 \pm 2,89^{\mathrm{a}}$ & $85,33 \pm 0,76^{\mathrm{bc}}$ & $83,83 \pm 3,40^{\mathrm{c}}$ \\
$\begin{array}{l}\text { Berat karkas (kg) (carcass weight } \\
(\mathrm{kg}))\end{array}$ & $65,00 \pm 2,65^{\mathrm{a}}$ & $67,83 \pm 0,58^{\mathrm{a}}$ & $60,33 \pm 0,29^{\mathrm{b}}$ & $53,50 \pm 1,80^{\mathrm{c}}$ \\
$\begin{array}{l}\text { Persentase karkas (\%) (carcass } \\
\text { percentage (\%)) }\end{array}$ & $72,88 \pm 0,96^{\mathrm{a}}$ & $73,51 \pm 2,09^{\mathrm{a}}$ & $70,71 \pm 0,33^{\mathrm{a}}$ & $63,86 \pm 2,55^{\mathrm{b}}$ \\
Loin eye area $\left(\mathrm{cm}^{2}\right)$ & $35,00 \pm 3,61^{\mathrm{ab}}$ & $35,67 \pm 2,52^{\mathrm{a}}$ & $30,33 \pm 1,53^{\mathrm{bc}}$ & $29,00 \pm 2,65^{\mathrm{c}}$ \\
TLP $(\mathrm{cm})$ & $3,55 \pm 0,16^{\mathrm{a}}$ & $3,20 \pm 0,17^{\mathrm{ab}}$ & $2,97 \pm 0,35^{\mathrm{b}}$ & $2,48 \pm 0,19^{\mathrm{c}}$ \\
\hline
\end{tabular}

R0: sekam padi $0 \%$, R1: sekam padi $10 \%$, R2: sekam padi $20 \%$, R3: sekam padi $30 \%$ (R0: $\% \%$ rice hull, $R 1$ : $10 \%$ rice hull, $R 2: 20 \%$ rice hull, $R 3: 30 \%$ rice hull).

TLP: tebal lemak punggung (backfat thickness).

a,b,c Superskrip yang berbeda pada baris yang sama menunjukkan perbedaan yang nyata $(\mathrm{P}<0,05)($ different superscripts at the same row indicate significant differences $(P<0.05))$.

daripada R3 (Tabel 3). Perbedaan ini disebabkan oleh berat badan akhir maupun berat potong ternak babi dari masing-masing kelompok tersebut yang memang lebih tinggi. Pemberian sekam padi dalam ransum yang mengakibatkan perbedaan tingkat pertumbuhan ternak babi selama dipelihara pada akhirnya akan mempengaruhi berat karkas yang dihasilkan. Penurunan berat karkas kelompok R3 juga akibat rerata berat kepala, kaki depan, dan belakang pada kelompok R0, R2, dan R3 yang hampir sama yaitu secara berturut-turut 4,$93 ; 1,02$ dan $1,22 \mathrm{~kg}$, serta berat beberapa organ dalam seperti empedu, lambung, sekum dan usus besar kelompok R3 yang lebih tinggi daripada R0 dan R2. Hasil ini sesuai dengan yang diperoleh Len et al. (2008), yaitu pemberian serat pada konsentrasi tinggi dalam ransum akan menurunkan berat karkas ternak babi masa pertumbuhan.

Persentase karkas kelompok R0, R1, dan R2 lebih tinggi $(\mathrm{P}<0,05)$ daripada R3 (Tabel 3). Hasil ini disebabkan karena berat karkas ternak babi kelompok R3 jauh lebih rendah daripada ketiga perlakuan lainnya. Hasil ini sesuai dengan penelitian Knowles et al. (1998) dan Len et al. (2008) yang mendapatkan bahwa pemberian serat dalam ransum ternak babi pada konsentrasi yang tinggi akan menurunkan persentase karkas segar yang dihasilkan.

Loin eye area kelompok R1 lebih luas $(\mathrm{P}<0,05)$ daripada $\mathrm{R} 2$ dan $\mathrm{R} 3$, demikian pula loin eye area kelompok $\mathrm{R} 0$ lebih luas $(\mathrm{P}<0,05)$ daripada R3 (Tabel 3). Pemberian sekam padi pada konsentrasi $10 \%$ dapat meningkatkan konsumsi pakan yang memungkinkan terpenuhinya kebutuhan nutrien ternak babi untuk pembentukan otot loin. Peningkatan pemberian sekam padi selain menyebabkan lambung ternak babi cepat penuh karena sifat bulky yang dimiliki sekam padi, juga berakibat pada peningkatan gerak laju digesta sehingga penyerapan nutrien menjadi berkurang. Hal ini sesuai dengan pendapat Demigne et al. (2001) yang menyatakan bahwa konsumsi serat menyebabkan peningkatan waktu transit dari mulut sampai ke sekum, menurunkan laju aliran asam empedu ke usus halus, sehingga akan menurunkan laju pergantian sirkulasi enterohepatik. Hasil ini sesuai dengan yang pernah dilaporkan oleh Shriver et al. (2003), Myer et al. (1999) dan Knowles et al. (1998), yaitu peningkatan serat kasar dalam ransum pada konsentrasi yang paling tinggi akan menurunkan loin eye area.

Lemak punggung kelompok R0 lebih tebal $(\mathrm{P}<0,05)$ daripada $\mathrm{R} 2$ dan $\mathrm{R} 3$, demikian pula pada kelompok R1 lebih tebal $(\mathrm{P}<0,05)$ daripada $\mathrm{R} 3$ (Tabel 3). Pemberian limbah pangan hotel tanpa sekam padi menyebabkan lemak ransum mampu diserap dan ditimbun di bawah kulit sebagai cadangan energi tubuh. Penurunan tebal lemak punggung dengan peningkatan sekam padi dalam ransum terjadi karena sekam padi mampu mengikat lemak ransum untuk diekskresikan bersama dengan feses. Hal ini sesuai dengan pendapat Jurkonski et al. (2008) yang menyatakan bahwa partikel serat umumnya memiliki gugus penukar ion kation yang memiliki kemampuan seperti matriks spons untuk mengikat partikel lemak dengan ikatan intraluminal. Hasil ini sesuai dengan yang pernah dilaporkan oleh Wilfart et al. (2007), bahwa peningkatan konsentrasi serat dalam ransum menyebabkan peningkatan kandungan ekstrak ether feses ternak babi.

\section{Kesimpulan}

Penggunaan sekam padi pada konsentrasi $10 \%$ dalam ransum berbasis limbah pangan hotel kering mampu meningkatkan pertumbuhan, berat potong, berat karkas, persentase karkas, dan loin eye 
area, tetapi belum mampu menurunkan tebal lemak punggung ternak babi.

\section{Daftar Pustaka}

Badan Pusat Statistik. 2012. Statistik Peternakan Indonesia. Available

at http://www.bps.go.id/tab_sub/view.php?kat= $3 \&$ tabel $=1 \&$ daftar $=1 \&$ id_subyek $=24 \&$ notab $=13$. Accession date: $25^{\text {th }}$ June 2013.

Bidura, I. G. N. G., I. B. Gaga Partama, dan T. G. O. Susila. 2008. Limbah Pakan Ternak Alternatif dan Aplikasi Teknologi. Udayana University Press. Denpasar.

Boggs, D. L., R. A. Merkel, M. E. Doumit and K. W. Bruns. 2006. Livestock and Carcasses: an Integrated Approach to Evaluation, Grading, and Selection. $6^{\text {th }}$ ed. Kendall/Hunt Publishing Co., Dubuque, Iowa.

Budaarsa, K. 1997. Kajian penggunaan rumput laut dan sekam padi sebagai sumber serat dalam ransum untuk menurunkan lemak karkas dan kolesterol daging babi. Disertasi Institut Pertanian Bogor, Bogor.

Chae, B. J., S. C. Choi, Y. G. Kim, C. H. Kim and K. S. Sohn. 2000. Effects of feeding dried food waste on growth and nutrient digestibility in growing-finishing pigs. AsianAust. J. Anim. Sci. 13: 1304-1308.

Demigne, C., C. Remesy and C. Morand. 2001. Resistant starches and lipid metabolism. Susan Cho, S. and M. L. Dreher (eds.). Handbook of Dietary Fiber. Marcel Decker, Inc, New York. Pp. 155-164.

Fraga, M. J., P. Perez de Ayala, R. Carabano and J. C. de Blas. 1991. Effect of type of fiber on the rate of passage and on the contribution of soft feces to nutrient intake of finishing rabbits. J. Anim. Sci. 69: 1566-1574.

Harris, T. G. 2002. Training Manual for USDA Standards for Grading Slaughter Animals: Slaughter Hog Grading. Georgia Agriculture Education Curriculum Office, University of Georgia, Georgia.

Jin, L., L. P. Reynolds, D. A. Redmer, J. S. Caton and J. D. Crenshaw. 1994. Effects of dietary fiber on intestinal growth, cell proliferation, and morphology in growing pigs. J. Anim. Sci. 72: 2270-2278.

Jurkonski, A., J. Juskiewicz and Z. Zdunczyk. 2008. Comparative effect of different dietary levels of cellulose and fructooligosacharides on fermentative process in the caecum of rats. J. Anim. Feed Sci. 17: 88-99.
Knowles, T. A., L. L. Southern, T. D. Bidner, B. J. Kerr and K. G. Friesen. 1998. Effect of dietary fiber or fat in low-crude protein, crystalline amino acid-supplemented diets for finishing pigs. J. Anim. Sci. 76: 2818-2832.

Kyriazakis, I. and C. T. Whittemore. 2006. Conclusion. In: Whittemore's Science and Practice of Pig Production. Kyriazakis, I. and C. T. Whittemore (eds.). Vol. 3. Blackwell Publishing Ltd., Oxford. Pp. 645-658.

Len, N. T., J. E. Lindberg and B. Ogle. 2008. Effect of dietary fiber level on the performance and carcass traits of mong cai, F1 crossbred (Mong cai $\times$ Yorkshire) and Landrace $\times$ Yorkshire pigs. Asian-Aust. J. Anim. Sci. 21: 245-251.

Mastika, I. M. 2009. Potensi limbah pertanian dan industri pertanian serta pemanfaatannya untuk makanan ternak. In: Pemikiran Kritis Guru Besar Universitas Udayana Bidang Agrokomplek (ed). Vol. 2. Udayana University Press, Denpasar.

Myer, R. O., J. H. Brendemuhl and D. D. Johnson. 1999. Evaluation of dehydrated restaurant food waste products as feedstuffs for finishing pigs. J. Anim. Sci. 77: 685-692.

National Research Council. 1998. Nutrient Requirements of Swine (ed). Vol. 10. National Academy Press, Washington. Pp. 110-123.

Noblet, J. and G. Le Goff. 2001. Effect of dietary fibre on the energy value of feeds for pigs. Anim. Feed Sci. Technol. 90: 35-52.

Shriver, J. A., S. D. Carter, A. L. Sutton, B. T. Richert, B. W. Senne and L. A. Petty. 2003. Effects of adding fiber sources to reducedcrude protein, amino acid-supplemented diets on nitrogen excretion, growth performance, and carcass traits of finishing pigs. J. Anim. Sci. 81: 492-502.

Statistical Product and Service Solutions Inc. 2007. SPSS Base 16.0 User's Guide. Available at http://www.spss.com. Accession date: $25^{\text {th }}$ June 2013.

Steel, R. G. D. and J. H. Torrie. 1993. Prinsip dan Prosedur Statistika. Suatu Pendekatan Biometrik. Penerjemah: Sumantri, B. Gramedia Pustaka Utama, Jakarta.

Wenk, C. 2001. The role of dietary fibre in the digestive physiology of the pig. J. Anim. Feed Sci. Technol. 90: 21-33.

Westendorf, M. L. 2000. Food waste as animal feed: an introduction. In: Food Waste to Animal Feed. Westendorf, M. L. (ed.). Vol. 1. Iowa State University Press, Iowa. Pp. 3-15. 
Westendorf, M. L., Z. C. Dong and P. A. Schoknecht. 1998. Recycled cafeteria food waste as a feed for swine: nutrient content, digestibility, growth, and meat quality. J. Anim. Sci. 76: 2976-2983.

Whittemore, C. T. and I. Kyriazakis. 2006. Growth and body composition change in pigs. In: Whittemore's Science and Practice of Pig Production. Kyriazakis, I. and C. T. Whittemore (eds.). Vol. 3. Blackwell Publishing Ltd. Oxford. Pp. 65-103.

Wilfart, A., L. Montagne, P. H. Simmins, J. van Milgen and J. Noblet. 2007. Sites of nutrient digestion in growing pigs: effect of dietary fiber. J. Anim. Sci. 85: 976-983.
Yadnya, T. G. dan N. M. S. Sukmawati. 2006. Pengaruh penggantian dedak padi dengan sekam padi atau serbuk gergaji kayu yang disuplementasi dengan probiotik terhadap efisiensi penggunaan ransum dan kadar asam urat darah itik bali. Majalah Ilmiah Peternakan 9: 40-44.

Yanis, M., D. Zainuddin, R. W. Suryawati, dan M. D. Rochjat. 2000. Pemanfaatan Limbah Restoran untuk Ransum Ayam Buras. Badan Penelitian dan Pengembangan Pertanian, Jakarta. ISBN: 979-96015-0-9. 